\title{
Comparison of the reaction of barley plants to treatment with microorganisms producing auxins and cytokinins
}

Akhtyamova Z.A.

Ufa Institute of Biology, Ufa Federal Research Center, Russian Academy of Sciences, Ufa

Email: akhtyamovazarina@gmail.com

Key message. We studied the effect of bacterization of seedlings of barley plants with strains of hormone-producing bacteria B. subtilis IB-22 and P. mandelii IB-Ki14. The parameters of plant growth, as well as RWC and the content of chlorophyll in their leaves were estimated.

Keywords: Hordeum vulgare L., growth, growth-stimulating bacteria

The ability of many strains of rhizospheric bacteria to stimulate plant growth and increase their productivity is increasingly used in crop production. The purpose of this work was to evaluate in detail the growth reaction of the shoots and roots of barley plants to bacterization of their seeds and to identify the peculiarities of the plants' response to treatment with bacteria that can mainly produce cytokinins or auxins. Barley plants were inoculated with the cytokinin-producing bacteria $B$. subtilis IB-22 (Arkhipova et al., 2006) and the auxin-producing bacteria P. mandelii IB-Ki14 (Kuzmina et al., 2018) from the collection of microorganisms of the Ufa Institute of Biology of the UFRC RAS. Bacterization of daily seedlings was carried out by soaking in suspension for 20 minutes and then introducing a suspension of bacteria into the root environment of plants ( $10^{6} \mathrm{CFU} / \mathrm{g}$ of soil). On the eleventh day from the beginning of the experiment, the fresh mass of shoots and roots, the length of the longest root, and the relative water content and chlorophyll in the leaves were evaluated; the length and width of the leaves was mesured every two days from the appearance of the seedlings. P. mandelii IB-Ki14 showed their growth stimulating effect during the first days after bacterization, but by the end of the experiment it no longer appeared. The most stable effect from treatment with $B$. subtilis IB-22 strain was the shortening of plant roots, which persisted throughout the experiment. The beneficial effect of bacteria of $B$. subtilis IB-22 strain on barley plants was manifested in their effect on the relative water content and concentration of chlorophyll. An increase in the concentration of chlorophyll in the leaves contributed to a more rapid accumulation of plant biomass treated with bacteria of the B. subtilis IB-22 strain. Thus, this work demonstrates the greater effectiveness of the B. subtilis IB-22 strain in stimulating the growth of barley plants and the associated physiological processes.

\section{Сравнение реакции растений ячменя на обработку микроорганизмами, продуцирующими ауксины и цитокинины \\ Ахтямова 3.A.}

Уфимский институт биологии Уфимского федерального исследовательского центра РАН, Уфа

\begin{abstract}
Аннотация. Изучалось влияние бактеризащии проростков растения ячменя штаммами гормонпродущирующих бактерий B. subtilis IB-22 и P. mandelii IB-Ki14. Оценивались параметры роста растений, а также ОСВ и содержание хлорофилла в их листьях.
\end{abstract}

Ключевые слова. Hordeum vulgare L., pост, рост-стимулирующие бактерии

Способность многих штаммов ризосферных бактерий стимулировать рост растений и повышать их урожайность все шире используют в растениеводстве. Цель данной работы состояла в детальной оценке ростовой реакции побегов и корней растений ячменя на бактеризацию их семян и в выявлении особенностей реагирования растений на обработку бактериями, способными преимущественно продуцировать цитокинины или ауксины. Для инокуляции растений ячменя использовали цитокининпродуцирующие бактерии B. subtilis IB-22 (Архипова и др., 2006) и ауксинпродуцирующие бактерии P. mandelii IB-Кi14 (Кузьмина и др., 2018) из коллекции микроорганизмов Уфимского института биологии УФИЦ РАН. Бактеризацию суточных проростков проводили путем замачивания в суспензии в течение 20 минут и последующим внесением суспензии бактерий в прикорневую среду растений (10 6 КОЕ / г почвы). На одиннадцатые сутки с начала эксперимента оценивали сырую массу побегов и корней, длину самого длинного корня, а также относительное содержание воды и хлорофилла в листьях; длину и ширину листьев оценивали каждые два дня с момента появления всходов. Бактерии P. mandelii IB-Кі14 проявляли свой рост стимулирующий эффект в первые дни после бактеризации, но к концу эксперимента он уже не проявлялся. Наиболее стабильным эффектом от обработки штаммом B. subtilis IB-22 было укорочение корней растений, сохраняющееся на протяжении всего эксперимента. Благоприятное действие бактерий штамма B. subtilis IB-22 на растения ячменя проявлялось в их влиянии на относительное содержание воды и концентрацию хлорофилла. Повышение концентрации хлорофилла в листьях способствовало более быстрому накоплению биомассы растений, обработанных бактериями штамма B. subtilis IB-22. Таким образом, данная работа свидетельствует о большей эффективности штамма B. subtilis IB-22 в стимуляции роста растений ячменя и связанных с ним физиологических процессов. 